Studia Oecumenica 17 (2017)

DOI: $10.25167 / \mathrm{SOe} / 17 / 2017 / 305-320$

JÓZEF BUDNIAK

Wydział Teologiczny UŚ

\title{
Chrzest i Eucharystia w praktyce ekumenicznej Kościoła katolickiego i luterańskiego
}

\author{
Baptism and Eucharist in Ecumenical Practice \\ of Catholic Church and Lutheran Church
}

\begin{abstract}
Summary
In the constant ecumenical quest, there is a tendency nowadays to reach the most basic levels of church life in order to put the ecumenical rules into practice. The time has come to concentrate our attention on this very level of church life. It is here, in the pastoral work, where we approach couples and families of different confessions. The issue arises now with redoubled strength because of great migrations of people on the European continent. The problem of mixed couples is, among other problems, a challenge in solving the question of baptism and taking Communion. That is why, the everyday life of believers opens on newer and newer experiences, also in the field of ecumenism. Analysing some texts concerning the issue of ecumenical dialogue dealing with baptism and Eucharist, we can find a confirmation of the thesis that it is the parish which should be the unquestionable role model of ecumenical movement.
\end{abstract}

Keywords: Catholic Church, Lutheran Church, baptism, Eucharist, ecumenism, dialogue.

\section{Streszczenie}

W poszukiwaniach ekumenicznych schodzimy na coraz bardziej podstawowe poziomy życia kościelnego, by na nich starać się wprowadzać w życie zasady ekumeniczne. Pytanie o ekumenizm w wymiarze parafialnym jest więc jak najbardziej uzasadnione. To na płaszczyźnie duszpasterstwa parafialnego coraz częściej spotykamy się z małżeństwami i rodzinami o różnej przynależności wyznaniowej. Do tego przyczyniają się choćby wielkie migracje ludności na kontynencie europejskim. Małżeństwa mieszane są m.in. wyzwaniem dla rozwiązywania problemów związanych z chrztem i przystępowaniem do Komunii św. Stąd życie powszednie wierzących otwiera się na coraz to nowe doświadczenia, także w dziedzinie ekumenizmu. Analizując poszczególne teksty związane z dialogiem ekumenicznym dotyczącym chrztu i Eucharystii, znajdujemy potwierdzenie tezy, że to parafia powinna być niekwestionowanym prekursorem ruchu ekumenicznego.

Słowa kluczowe: Kościół katolicki, Kościół luterański, chrzest, Eucharystia, ekumenizm, dialog. 
Ruch ekumeniczny ma swoje korzenie w ruchach odnowy życia eklezjalnego, które dokonują się wewnątrz Kościołów i Wspólnot chrześcijańskich, sięgając poza granice wyznaniowe. W większości przypadków ekumeniczne współistnienie i współpraca charakteryzują codzienne życie kościelne w parafiach i diecezjach. W ten sposób, co dnia, realizowany jest „testament” pozostawiony przez Jezusa Jego uczniom, choć niejednokrotnie jego realizacja związana jest z przezwyciężaniem wszelkich ewentualnych trudności, nieporozumień, a nawet niepowodzeń. Ekumenizm nacechowany jest ciągłymi staraniami o stworzenie jak najlepszych warunków do szerokiego dialogu i solidarnej współpracy między wszystkimi wyznawcami jednego Boga, by ustanowić więź głębokiej komunii, wszak, „żyjemy dzięki Bogu, przed Bogiem i możemy żyć z Bogiem”.

Życie powszednie wierzących otwiera się na coraz to nowe doświadczenia, także w dziedzinie ekumenizmu. Przyczyniają się do tego choćby wielkie migracje ludności na kontynencie europejskim, a konsekwencją tego są rodziny wielowyznaniowe. Stąd priorytetem duszpasterstwa ekumenicznego winna być chrześcijańska rodzina wielowyznaniowa, w której nierzadko pojawiają się takie problemy, jak: chrzest, wychowanie chrześcijańskie potomstwa, praktyki pobożnościowe i ślub. Już przed zawarciem ślubu przez nupturientów o różnej przynależności wyznaniowej Kościół zwraca uwagę na przygotowanie ich nie tylko do ślubu, lecz również do przyszłego życia. O tym wspomniał papież Paweł VI w motu proprio „Matrimonia mixta” z 31 marca 1970 r.: „Liczne (...) trudności związane są z samym małżeństwem mieszanym. (...) wprowadza się pewien rozdział do żywej komórki Kościoła, jak słusznie nazywa się rodzinę chrześcijańską. Ponadto staje się trudniejszą rzeczą wypełnienie przez rodzinę nakazów ewangelicznych ze względu na różność spraw religijnych. Dotyczy to w pierwszym rzędzie uczestnictwa w kulcie religijnym Kościoła i wychowania potomstwa (...). W małżeństwie mieszanym strona katolicka ma nie tylko obowiązek zachowania wiary, lecz również troszczenia się - na ile to możliwe - o ochrzczenie potomstwa, wychowanie w wierze katolickiej i zapewnienie mu wszystkich środków zbawienia wiecznego, jakich Kościół użycza swoim dzieciom”’.

Jak zatem w duszpasterskiej praktyce ekumenicznej Kościoła katolickiego i luterańskiego wygląda kwestia chrztu i udział w Eucharystii? Pytanie o chrzest i Eucharystię w ekumenicznym wymiarze duszpasterstwa parafialnego (czyli w codziennej praktyce Kościołów katolickiego i luterańskiego w Polsce) jest jak najbardziej uzasadnione; co więcej, nadszedł już odpowiedni czas, by skoncentrować się na tym poziomie życia kościelnego. Chrzest i Eucharystia to dwa sakramenty uznawane przez wszystkich chrześcijan. Co do chrztu świętego panuje

\footnotetext{
1 G. Ebeling, Sui Salmi, Brescia 1971, 97.

${ }^{2}$ Por. E. Sztafrowski, Posoborowe prawo kościelne, t. III, z. 2, Warszawa 1971, 10.
} 
zasadnicza zgoda. Chrzest udzielony w jednym z Kościołów jest uznawany za ważny w innych. W Polsce ta zgoda została przypieczętowana specjalną deklaracją. Podpisało ją w 2000 r. siedmiu zwierzchników Kościołów chrześcijańskich. Zatem zanim podjęta zostanie kwestia chrztu i Eucharystii, zostanie zaprezentowane duszpasterstwo małżeństw osób o różnej przynależności wyznaniowej, w nich bowiem najczęściej występuje problem tych sakramentów.

\section{Duszpasterstwo małżeństw i rodzin o różnej przynależności wyznaniowej}

We wszystkich cywilizacjach istnieją takie instytucje społeczne, jak małżeństwo i rodzina, które są początkiem i fundamentem ludzkiej społeczności. Księga Rodzaju, mówiąc o konstytuowaniu się rodziny poprzez małżeństwo, stwierdza: „(...) mężczyzna opuszcza ojca swego i matkę swoją i łączy się ze swą żoną tak ściśle, że stają się jednym ciałem" (Rdz 2,24). Małżeństwo zatem zostało ustanowione, stworzone i pobłogosławione przez Boga już od zarania ludzkości.

W religii chrześcijańskiej małżeństwo jest przedstawiane jako Dobra Nowina: wzajemna i piękna, jedyna i nierozerwalna więź między mężczyzną i kobietą powołanymi do dawania życia. Małżonkowie w tym sakramencie odnajdują odwagę potrzebną do otwarcia się na drugiego człowieka, do przebaczania, do dialogu i jedności serc ${ }^{3}$. Kościół troszczy się o każde małżeństwo, o jego trwałość i nierozerwalność. Dlatego specjalną troską duszpasterską otaczane są małżeństwa osób o różnej przynależności wyznaniowej, popularnie zwane małżeństwami mieszanymi ${ }^{4}$. Związki te niosą często ze sobą trudności w zachowywaniu wiary, jak i harmonii życia rodzinnego. Początkowa forma duszpasterstwa małżeństw mieszanych ma miejsce już na etapie przygotowania i celebracji takiego małżeństwa. Duszpasterze obowiązani są kierować się tutaj nauką i zaleceniami swoich Kościołów, które pozwalają nadać zarówno przygotowaniu, jak i celebracji takiego małżeństwa charakter ekumeniczny. Duszpasterze winni dołożyć wszelkich starań o to, aby zawarcie sakramentalnego związku małżeńskiego odbyło się z zachowaniem formy kanonicznej. Należy zwrócić uwagę na okoliczności odstąpienia od formy, jak również na całkowitą swobodę decyzji, jaką mają sami narzeczeni w sprawie wyboru Kościoła, w którym chcą zawrzeć związek małżeński. Nupturientów należy poinformować o możliwości udziału księdza katolickiego na życzenie młodej pary podczas ślubu mieszanego, zawieranego na podstawie dyspensy w Kościele ewangelickim.

3 Przemówienie Jana Pawła do przedstawicieli Equipe Notre-Dame wygłoszone 20 stycznia 2003 roku: Eucharystia źródtem sity dla matżonków i rodziców, OsRomPol (2003) nr 3, 25.

${ }^{4}$ Por. KPK 1124; KPK 1086; 1071, § 1, 40, § 2. 
Różnice wyznaniowe w małżeństwie i w rodzinie wskazują, jak wielkie znaczenie ma wzajemne poszanowanie wolności religijnej, która może być naruszona „tak przez naciski zmierzające do zmiany przekonań religijnych partnera, jak przez stawianie przeszkód swobodnemu ich wyrażaniu poprzez praktyki religijne" (FC 78) ${ }^{5}$. Mogą one wpływać również na stopień zaangażowania chrześcijańskiego i wywierać wpływ na harmonię życia rodzinnego. „Rozbieżności dotyczące wiary, samej koncepcji małżeństwa, a także odmiennych mentalności religijnych mogą stanowić źródło napięć w małżeństwie, zwłaszcza w odniesieniu do wychowania dzieci” (KKK 1634). W takich sytuacjach małżeństwa mogą liczyć na pomoc płynącą z duszpasterstwa małżeństw mieszanych w „przezwyciężeniu napięć między zobowiązaniami, jakie małżonkowie mają wobec siebie, a zobowiązaniami wobec swoich wspólnot eklezjalnych. Powinno ono zachęcać do rozwijania tego, co jest wspólne w ich wierze, i do uszanowania tego, co ich dzieli" (KKK 1636).

Działalność duszpasterstwa ekumenicznego winna kierować się m.in. następującymi zasadami: zachęcanie wiernych do modlitwy o jedność chrześcijan; udział we wspólnych nabożeństwach i innych formach działalności parafii; wzbogacanie wiedzy o Kościołach; przypominanie rodzicom, że dziecko mimo przynależności do jednego z Kościołów powinno być edukowane o duchowym bogactwie drugiego Kościoła przez udział w uroczystościach kościelnych. Tak rozumiane duszpasterstwo ekumeniczne, które w rzeczywistości jest formą dialogu wiary w rodzinie, może służyć umocnieniu miłości małżonków, będącej zarazem przykładem miłości ekumenicznej i znakiem jedności dla podzielonego Kościoła. Kościoły chrześcijańskie w oparciu o małżeństwa i rodziny o różnej przynależności wyznaniowej mogą w życiu codziennym realizować praktyczny, żywy i dynamiczny ekumenizm ${ }^{6}$.

Dobrą okazję do zapoznania się z rodzinami o różnej przynależności wyznaniowej, ich problemami i oczekiwaniami, stanowią ekumeniczne wizyty duszpasterskie, czyli wspólne odwiedziny duszpasterzy - katolickiego i ewangelickiego - w ramach tzw. „kolędy”. Najczęściej odwiedziny te są w okresie Bożego Narodzenia i polegają na wspólnej ze wszystkimi członkami rodziny modlitwie, śpiewaniu kolęd, wspólnych przecież dla obu Kościołów, rozmowach i udzieleniu im przez obu księży błogosławieństwa. Odwiedziny te są niejednokrotnie okazją do zapoznania się z rodzinami mieszanymi wyznaniowo, gdzie często spotyka się takie małżeństwa, które miały ślub w Kościele ewangelickim bez dyspensy od formy kanonicznej. Często podczas odwiedzin

\footnotetext{
${ }_{5}^{5}$ JAN PAWEe II, Adhortacja apostolska o zadaniach rodziny chrześcijańskiej w świecie wspótczesnym „Familiaris consortio” (dalej: FC), Watykan 1981.

${ }^{6} \mathrm{~K}$. KocH, Dzięki malżeństwom mieszanym możemy realizować praktyczny ekumenizm, http:// niedziela.pl/ artykuł/18380/Kard-Koch-dzieki-malzenstwom-mieszanym (23.02.2017).
} 
duszpasterskich pojawiają się tematy odnośnie do chrztu dziecka i przystępowania do Komunii św. ${ }^{7}$

Sprawa małżeństw osób o różnej przynależności wyznaniowej nieustannie budzi wiele pytań i kontrowersji. Jednakże przy minimum dobrej woli każdej ze stron wszystkie problemy i trudności można rozwiązać. W sposób wyjątkowy o wspomaganie duchowe i intelektualne takich małżeństw powinni zadbać duszpasterze. Biskupi i kapłani „winni troszczyć się o to, ażeby katolickiemu małżonkowi i dzieciom zrodzonym z małżeństwa mieszanego nie zabrakło duchowej pomocy do wypełnienia ich obowiązków. Mają też wspierać małżonków w utrwaleniu jedności życia małżeńskiego i rodzinnego" (KPK 1128). Kościoły winny prowadzić intensywny dialog na temat ekumenicznego duszpasterstwa małżeństw i rodzin o różnej przynależności wyznaniowej, a duchowni obu wyznań powinni, w duchu miłości, otaczać opieką małżeństwa i rodziny niosące brzemię wyznaniowej różnorodności. Szczególnie w kwestii chrztu i wychowywania potomstwa podkreśla się, że przekazywanie wiary dzieciom jest sprawą rodziców, którzy mogą doprowadzić w rodzinie do dialogu ekumenicznego, dzieląc się wzajemnie „skarbem swej wiary”. Przynależność dzieci do jednego Kościoła powinna iść w parze $\mathrm{z}$ kształtowaniem ich postawy otwartości wobec drugiego Kościoła ${ }^{8}$, co w przyszłości może urzeczywistnić się w „ekumenii komunii"'.

\section{Chrzest w ekumenicznej praktyce Kościoła katolickiego i ewangelickiego}

Ewangelista Marek wskazał na słowa Jezusa, które wyznaczają zadania dla wszystkich chrześcijan: „Idźcie na cały świat i głoście Ewangelię wszelkiemu stworzeniu! Kto uwierzy i przyjmie chrzest, będzie zbawiony; a kto nie uwierzy, będzie potępiony" (Mk 16,14-16).

Chrystus wyznacza małżonkom zadanie, które polega m.in. na budowaniu Kościoła. Dokonuje się ono w różny sposób: małżonkowie, wydając potomstwo, przyczyniają się do liczebnego wzrostu Kościoła, a przez chrzest potomstwa, włączają je do wspólnoty Mistycznego Ciała Chrystusa ${ }^{10}$. Stanowisko Kościoła katolickiego

7 J. BudNIAK, Ekumenizm jutra na przyktadzie Śląska Cieszyńskiego, Katowice 2002, 145-146.

8 Wiara, modlitwa i życie w Kościele Katowickim. Uchwały I Synodu Diecezji Katowickiej 1972-1975, Katowice - Rzym 1976, 235-238.

${ }_{9}$ „Ekumenia komunii urzeczywistnia się przez coraz pełniejszą partycypację we wspólnych dobrach zbawienia, w jednej Ewangelii, w jednym Duchu, w jednym Jezusie Chrystusie, w jednym życiu Trójosobowego Boga". Por. A. Nossol, Wspólnota ekumeniczna - troska o budowe zjednoczonej Europy jako wspólnoty wartości i kultury, „Studia Oecumenica” 6 (2006), 171.

${ }^{10}$ M. Kaszowski, Podstawy nauki Kościoła katolickiego w pytaniach i odpowiedziach, www. teologia.pl, s.1 (28.01.2017). 
wobec chrztu zawarte zostało również w Dyrektorium w sprawie realizacji zasad $i$ norm dotyczacych ekumenizmu: „Przez sakrament chrztu osoba zostaje prawdziwie wcielona w Chrystusa i Kościół oraz odrodzona, aby mieć udział w życiu Bożym. Chrzest wprowadza sakramentalną więź jedności, istniejącej między tymi wszystkimi, którzy zostali przezeń odrodzeni. Chrzest sam z siebie jest początkiem, zmierza bowiem do nabycia pełni życia w Chrystusie. Jest zatem skierowany do wyznania wiary oraz do pełnej integracji w ekonomii zbawienia i do komunii eucharystycznej. Ustanowiony przez samego Chrystusa chrzest, przez który uczestniczy się w Jego śmierci i zmartwychwstaniu, zawiera w sobie nawrócenie, wiarę, odpuszczenie grzechu i dar łaski" (Dyr. Ek 92) ${ }^{11}$.

Stanowisko Kościoła ewangelickiego odnośnie do chrztu jest podobne do stanowiska Kościoła katolickiego. W Kościele ewangelickim chrzest jest sakramentem, który ustanowił Jezus Chrystus (Mt 28,19; Mk 16,16). Przez chrzest człowiek przyjmuje zbawienie, które Chrystus uzyskał dla niego na krzyżu i przez zmartwychwstanie. Chrzest jest konieczny do zbawienia, co podkreślone zostało w IX artykule Konfesji Augsburskiej ${ }^{12}$. Chrzest jest jeden, on jednoczy Kościól, włącza do niego ochrzczonych, jest niepowtarzalny. Znakiem chrztu jest woda. Chrzest jest dziełem Bożym, ma on to samo znaczenie co Słowo Boże. Jest on „słowem widzialnym”, jak Ewangelia jest „Sakramentem słyszalnym”. Duży Katechizm mówi, iż chrzest nie jest „zwykłą wodą, lecz wodą objętą Słowem Bożym i przykazaniem, i przez nie uświęconą, tak iż nie jest niczym innym, jak wodą Bożą”. Skoro w chrzcie łączy się z wodą Słowo Boże, to „wiąże z nim sam Bóg swój majestat i wkłada weń swoją moc, i potęgę. Tak więc w chrzcie łączy się rzecz naturalna - woda, z rzeczą Boską - ze Słowem. Gdy Słowo łączy się z żywiołem, czyli z naturalną substancją, staje się sakramentem, to jest świętą Boską rzeczą i znakiem"13.

Konkludując, według katolickiej i ewangelickiej wykładni o sakramentach chrzest jest bramą wszystkich sakramentów i konieczny do zbawienia ${ }^{14}$. Dla katolików i luteranów chrzest to znak jedności łączący wierzącego z Chrystusem oraz chrześcijan między sobą ${ }^{15}$. Podobnie jak Kościół katolicki, tak i Kościół

11 Papieska Rada ds. Jedności ChrZeŚCIJAn, Dyrektorium $w$ sprawie realizacji zasad i norm dotyczacych ekumenizmu (1993) (dalej: Dyr. Ek), ComP (1994), nr 2.

${ }^{12}$ Konfesja Augsburska IX. O chrzcie, http://old.luteranie.pl/www/biblioteka/dpisma/ka.pdf (04.02.2017).

${ }_{13}$ Sakrament chrztu świętego, w: M. LuTER, Mały katechizm, http://www.diec.warszawska. luteranie.pl/pobierz/Ma\%C5\%82y_Katechizm.pdf; TENŻE, Duży katechizm, http://luter2017.pl/wp-content/uploads/ pdf/Duzy Katechizm.pdf (12.02.2017).

${ }^{14}$ Por. KPK 849; także: Chrzest święty, http://luteranie.pl/w_co_wierzymy/chrzest_swiety. html (18.07.2016).

${ }^{15}$ Sakrament chrztu znakiem jedności. Deklaracja Kościołów w Polsce na progu trzeciego tysiaclecia (Warszawa, 23 stycznia 2000r.), w: J. BudniaK, Z. Glaeser, T. KaŁużNY, Z.J. KiJas (red.), Encyklopedia ekumenizmu w Polsce (1964-2014), Kraków 2016, 514-515, nr 2. 
ewangelicki zwraca uwagę, że rodzice biorą na siebie obowiązek odpowiedzialności za chrześcijańskie wychowanie dziecka. Ważną rolę w chrzcie dziecka spełniają osoby chrzestne. Jak naucza Kościół rzymskokatolicki, chrzestny ma obowiązek pomagać ochrzczonemu, aby żył w wierze chrześcijańskiej i w zażyłości z Chrystusem oraz spełniał obowiązki, które wypływają z chrztu. Według Kodeksu Prawa Kanonicznego chrzestnym powinien być katolik (por. KPK 872 i 874), a chrześcijanin innego wyznania może być jedynie świadkiem chrztu (por. KPK 874 § 2). Podobnie jest we wspólnocie ewangelicko-augsburskiej, gdzie chrzestny również ma uczyć ochrzczonego wiary. Dlatego wspólnota ewangelicko-augsburska w Polsce naucza, że chrzestny powinien być luteraninem lub członkiem wspólnoty, z którą Kościół ewangelicko-augsburski jest we wspólnocie ,ambony i ołtarza”. Poza tym luteranie pozwalają, aby chrzestnym został również inny chrześcijan (np. ze względu na więzy rodzinne) ${ }^{16}$. Taka praktyka duszpasterska dotycząca chrztu w obu wyznaniach jest konieczna, ponieważ chrześcijanin wychowany jest w konkretnej wierze, którą przedstawia Kościół lub wspólnota eklezjalna ${ }^{17}$.

W praktyce Kościoła aż do Soboru Watykańskiego II chrzest dziecka z małżeństwa mieszanego nie prowadził do jakichkolwiek kontrowersji. Na taką sytuację m.in. wpłynęła decyzja cesarza Fryderyka II Hohenzollerna z 1743 r., który dał pruskim i śląskim ewangelikom równouprawnienie z katolikami. Od tamtego czasu dzieci są chrzczone i wychowywane w wyznaniu rodziców, a więc dziewczynki w wyznaniu matki, a chłopcy - ojca ${ }^{18}$. Ta praktyka do dziś trwa na Śląsku Cieszyńskim.

Po Soborze Watykańskim II sytuacja się zmieniła. Decyzja, w którym Kościele ma być dziecko ochrzczone, nie była łatwa i prowadziła do wielu nieporozumień, były to po prostu ,przepychanki”, które kończyły się tym, że dziecko było dwa razy chrzczone, czyli w Kościele katolickim i w ewangelickim.

Bardziej skomplikowaną sprawą są małżeństwa mieszane, gdzie jeden z rodziców pochodzi np. ze Śląska Cieszyńskiego i jest wyznania luterańskiego, a drugi spoza tego regionu i jest wyznania katolickiego. Oto przykład: ślub zawarli w kościele katolickim w Oświęcimiu ku niezadowoleniu rodziny ewangelickiej. Kiedy na świat przyszło pierwsze dziecko, katolicka babcia udała się z dzieckiem na spacer i wówczas na własną rękę, ale umówiona wcześniej z proboszczem, udała się do kościoła katolickiego, by tam je ochrzcić. Po urodzeniu się drugiego dzie$\S 74$.

${ }_{16}$ Pragmatyka Stużbowa Kościoła Ewangelicko-Augsburskiego w Rzeczpospolitej Polskiej,

17 P. JASkóŁA, Zagadnienia ekumeniczne, Opole 2004, 62.

18 J.T. Maciuszko, Kościót luterański w Polsce od XVI do XX wieku, w: J. Below, M. Legendź (red.), Świadectwo wiary i życia Kościót luterański w Polsce wczoraj i dziś, Bielsko-Biała 2004, 55-104. 
cka z kolei ewangelicka babcia stała nad nim jak przysłowiowy diabeł nad duszą i dopilnowała, żeby zostało ochrzczone w kościele ewangelickim.

Kwestię sakramentu chrztu zaliczyć dziś można w poczet ekumenicznych sukcesów. 23 stycznia 2000 r. Kościół katolicki w Polsce i Kościoły zrzeszone w Polskiej Radzie Ekumenicznej podpisały deklarację o wzajemnym uznaniu sakramentu chrztu świętego. Oznacza to, że chrzest przyjęty w którymkolwiek z tych Kościołów zachowuje swoją ważność w innym i nie trzeba go powtarzać. Za ważny uznaje się więc chrzest udzielony w Kościele katolickim oraz w Kościołach: ewangelicko-augsburskim, ewangelicko-metodystycznym, ewangelicko-reformowanym, polskokatolickim, Polskim Autokefalicznym Kościele Prawosławnym oraz Starokatolickim Kościele Mariawitów. Deklaracja Kościotów w Polsce na progu trzeciego tysiaclecia kończy się optymistycznym - ekumenicznym - akcentem: „Chrzest w Chrystusie jest wezwaniem dla Kościołów, aby przezwyciężyły swoje podziały i w widzialny sposób zamanifestowały swoją wspólnotę"19.

Chrzest w praktyce Kościołów chrześcijańskich pokazuje, jak wielką jest wartością dla jedności chrześcijan. Jednocześnie jest on podstawą do tworzenia wspólnoty chrześcijańskiej - „ekumenii komunii”.

\section{Eucharystia w ekumenicznej praktyce Kościoła katolickiego i ewangeli- ckiego}

Brak wspólnoty eucharystycznej jest najbardziej bolesnym rozdarciem Kościoła. Problem tkwi już w samym rozumieniu Eucharystii jako komunii, która dla katolików i prawosławnych ma być znakiem jedności, a dla protestantów środkiem budowania jedności. Jest to ważny temat dogmatyczny w dialogu ekumenicznym. Nieporozumienia w tej kwestii dotyczą szczególnie przemiany eucharystycznej (transsubstancjacji), ofiarniczego charakteru Mszy św. oraz interkomunii, czyli tzw. „gościnności eucharystycznej”20. Dwa pierwsze tematy bardzo mocno akcentowali Marcin Luter i jego uczniowie ${ }^{21}$ (por. OKDK 142-148). Doprowadziło to do wielu zmian w rozumieniu i sprawowaniu tego sakramentu. Kiedy katolicy i luteranie myślą o wspólnym obchodzeniu 500 lat od wystąpienia Marcina Lutra, to nie powinni zapominać o tym, aby w kwestii Eucharystii rozważać co nas łączy, a co dzieli. Autorzy raportu Od konfliktu do

19 Sakrament chrztu znakiem jedności. Deklaracja Kościołów w Polsce na progu trzeciego tysiaclecia, 514-515.

${ }^{20}$ A. Nossol, Ekumenizm jako imperatyw chrześcijańskiego sumienia, Opole 2000, 32.

${ }^{21}$ Od konfliktu do komunii. Luterańsko-katolickie wspólne upamiętnienie reformacji w 2017 roku, (dalej: OKDK), Dzięgielów 2013, nr 3. 
komunii podkreślili, że „co do trwania obecności eucharystycznej ujawniają się różnice także w praktyce liturgicznej. Katolicy i luteranie wspólnie wyznają, że eucharystyczna obecność Pana Jezusa Chrystusa, choć ukierunkowana jest na przyjmowanie przez wiernych, nie ogranicza się jednak do momentu przyjmowania i że nie zależy od wiary przyjmującego w ten sposób, jak gdyby jej była przyporządkowana" (OKDK 155). Dokument zwrócił również uwagę, aby luteranie po liturgii komunijnej z szacunkiem obchodzili się z pozostałymi elementami eucharystycznymi. Jednocześnie tekst napomina katolików, aby zwracali uwagę na fakt, żeby praktyka eucharystycznej adoracji „nie stała w sprzeczności z powszechnym przekonaniem, że Eucharystia ma charakter posiłku" (OKDK 156).

Luterańsko-katolicki dokument przypomina, że oba wyznania doszły do porozumienia co do ofiarniczego charakteru Eucharystii. Zarówno Kościół rzymskokatolicki, jak i wspólnoty luterańskie uznają, że w czasie Wieczerzy Pańskiej dokonuje się uobecnienie ofiary Jezusa na Krzyżu i Jego zmartwychwstania, a nie przedłużenie tej ofiary, ani jej dopełnienie (por. OKDK 157-159). Jest to znaczny krok w stronę dialogu o Eucharystii. Autorzy raportu wspomnieli ponadto, że u luteranów Komunia św. jest przyjmowana pod dwiema postaciami: chleba i wina oraz, że oba wyznania uznają, że do Eucharystii mają być przeznaczone zarówno chleb, jak i wino (por. OKDK 160), a sprawowanie Eucharystii ma być pod przewodnictwem powołanego duchownego. Równocześnie zaznaczyli, że „urząd duchownego katolicy i luteranie rozumieją różnie" (OKDK 161).

W związku z rozumieniem urzędu między katolikami a luteranami pojawia się problem intercelebracji. Ponadto istnieje problematyczne zagadnienie interkomunii. Te dwa punkty bardzo mocno dzielą oba wyznania. Jeżeli chodzi o intercelebrację, to nauka Kościoła rzymskokatolickiego zabrania sprawowania Eucharystii z duchownymi niekatolickimi (por. KPK kan. 907). Każdy kapłan katolicki, który tak uczyni, powinien, być upomniany w odpowiedni sposób, zgodnie z przepisami prawa ${ }^{22}$. Taka praktyka jest stosowana, ponieważ zarówno ewangelicy, jak i katolicy rozumieją w różny sposób Eucharystię oraz kapłaństwo. Fakt, że tego sakramentu duchowni obu wyznań nie mogą sprawować razem, przynosi Kościołowi wielki ból. Nie może dojść do takiej sytuacji, jaka zaistniała między luteranami oraz innymi wspólnotami protestanckimi, którzy w 1973 r. - w wyniku podpisania Konkordii Leuenberskiej - zawarli wspólnotę „ambony i ołtarza”, czyli wspólną celebrację Wieczerzy Pańskiej, pomimo różnic dogmatycznych w tej kwestii ${ }^{23}$. Kościoły te nie są w komunii z Kościołem kato-

${ }^{22}$ K. Koch, R. BIEL, Symfonia jedności, Lublin 2015, 82. nr 1,21 .

${ }_{23}$ B. FERDEK, Encyklika ,Ecclesia de Eucharistia” w perspektywie ekumenicznej, WrPT (2003) 
lickim, o czym wspomniał Jan Paweł II w encyklice Ecclesia de Eucharistia ${ }^{24}$ : „Ponieważ właśnie jedność Kościoła, którą Eucharystia urzeczywistnia przez ofiarę i komunię z Ciałem i Krwią Pana, koniecznie domaga się pełnej komunii w zakresie wyznania wiary, sakramentów i władzy kościelnej, nie jest możliwe koncelebrowanie tej samej liturgii eucharystycznej, dopóki nie będzie na nowo przywrócona w pełni ta więź. Mogłaby okazać się «przeszkodą do osiągnięcia pełnej komunii», pomniejszając poczucie dystansu dzielącego nas od celu i wprowadzając lub uwiarygodniając nieścisłości w rozumieniu takiej czy innej prawdy wiary" (EE 44).

Kontynuując swą myśl na temat wspólnego sprawowania Eucharystii, Jan Paweł II zaznaczył, że „mimo to gorąco pragniemy odprawiać razem jedyną Eucharystię Chrystusa i to pragnienie już staje się wspólnym uwielbieniem i wspólną modlitwą błagalną. Razem zwracamy się do Ojca i czynimy to coraz bardziej jednym sercem" (EE 44). Oprócz tego istotnym zagadnieniem jest sprawa interkomunii. Jest ona bardzo ważna dla małżonków o różnej przynależności wyznaniowej, gdyż współmałżonek katolicki, uczestnicząc w nabożeństwie ewangelickim, chciałby przyjąć Komunię św., a nie może tego uczynić25. Dzieje się tak z tej samej przyczyny, jaka zachodzi w przypadku intercelebracji. Nie może dojść do interkomunii z wspólnotami protestanckimi, bo nie tworzymy jeszcze wspólnej komunii (wspólnoty) w ścisłym tego słowa znaczeniu. Istnieje jednak ekumeniczna nadzieja na dojście do pełnej komunii katolików i luteran. Istnieją normy, które pozwalają ewangelikom (oraz wiernym innych Kościołów i wspólnot kościelnych) przyjąć Komunię św. (oraz sakrament pokuty i namaszczenia chorych) od katolickiego kapłana ${ }^{26}$. Dzieje się tak ponieważ „celem jest zaspokojenie poważnej potrzeby duchowej dla zbawienia wiecznego poszczególnych wiernych, nie zaś realizowanie interkomunii, niemożliwej dopóty, dopóki nie będą w pełni zacieśnione widzialne więzy komunii kościelnej” (por. EE 45). Również katolickie prawo kanoniczne odwołuje się do tej zasady: „(...) zbawienie dusz zawsze winno być w Kościele najwyższym prawem” (kan. 1752). Okoliczności, które pozwalają na tę sytuację, określiło Dyrektorium ekumeniczne z 1993 r. Można udzielić wspomnianych sakramentów, jeśli: zaistniało niebezpieczeństwo śmierci, dana osoba nie ma możliwości przyjęcia tych sakramentów od duchownego swojego wyznania, dobrowolnie o nie poprosiła oraz gdy osoba wyraziła wiarę katolicką odnośnie do tych sakramentów i dyspozycji ich przyjęcia ${ }^{27}$.

24 Jan Pawee II, Encyklika „Ecclesia de Eucharistia” (dalej: EE), Wrocław 2003.

25 A. SKowroneK, Sakramenty wiary. Spotkania z Chrystusem w Kościele w profilu ekumenicznym, t. V, Włocławek 1998, 93.

${ }^{26}$ P. JASKÓŁA, Zagadnienia ekumeniczne, 65-66.

27 J. BuDNIAK, W jakich okolicznościach można udzielić Komunii św. niekatolikom, HD (2008) nr 1, 129-135; także Dyr. Ek 130-131. 
Należy wyraźnie dostrzegać trudności, które stoją przed małżeństwami mieszanymi. Przykładem tej kwestii są słowa zawarte w liście napisanym przez katolika do księdza katolickiego: „Jestem katolikiem, życzliwie i z nadzieją patrzącym na współistnienie różnych wyznań. Bo mam to w domu jako codzienność. (...) Podczas gdy docierają do mnie echa dyskusji, jak przyjmować Komunię św., mnie dręczy inny problem. Bardzo pragnąłbym przyjmować Pana Jezusa wraz z moim synem, który parę lat temu przystąpił do konfirmacji. Ożywiłoby to więź rodzinną i religijną w kręgu moich najbliższych. Wpłynęłoby też, jako dobry przykład, na wychowanie mego syna. Jest $\mathrm{w}$ wieku, kiedy najbardziej potrzebuje mojego dobrego wzorca. Z szacunkiem do mojego Kościoła i tradycji, w jakiej zostałem wychowany, dotychczas nie podjąłem próby przystąpienia do Stołu Pańskiego poza Kościołem katolickim. Czy jestem skazany na pasywność? W czasie rozmowy z pastorem i babcią mego syna zdobyłem pełną akceptację. Przemogłem już w sobie ów dystans, jaki dzieli różnych wyznawców i chętnie uczestniczę razem z rodziną w nabożeństwach w Kościele ewangelickim. Bardzo mnie to buduje, gdy mogę wraz z innymi śpiewać dotąd nieznane, a pełne uwielbienia Pana Boga, pieśni. Wiem, że w Komunii św. Jezus uświęca nas i całe nasze życie. W ostatnim czasie rozdarcie chrześcijaństwa odczułem na nowo. Proszę więc o pociechę, o modlitwę, abym mógł razem z moim synem gościć przy wspólnym stole eucharystycznym Gościa Najdroższego, Jezusa"28.

Kolejny przykład: „Moim «problemem» jest małżeństwo mieszane. Ja jestem chrześcijaninem wyznania ewangelicko-augsburskiego (luteraninem), moja żona jest katoliczką. Jesteśmy razem 20 lat. Mamy 2 dzieci (17 i 6 lat). Żeniąc się, zdawałem sobie w pełni sprawę z trudności, które mnie czekają. Przez te 20 lat - tak było prościej - chodzę do kościoła katolickiego i z wielkim wysiłkiem nauczyłem się zwracać uwagę na to, co łączy - nie dzieli. Od czasu do czasu chodzę do kościoła «do siebie» (tylko jedno nabożeństwo, w innej dzielnicy - to podstawowa trudność). Zaakceptowałem ten stan rzeczy, ale jestem przywiązany do mojego wyznania - konwersja nigdy nie wchodziła w grę - mimo trudności które mam. I tu moje pytanie: Czy byłoby możliwe przystępowanie do Komunii w kościele katolickim i na jakich warunkach? Czy ksiądz mógłby mi coś więcej na ten temat powiedzieć, doradzić? Dodam, iż moje dzieci są (nie lubię tego zwrotu) wychowywane $\mathrm{w}$ wierze katolickiej - z tego prostego powodu, iż jest to sfera żony, akceptowałem to, a ponadto wierzę w chrześcijańską jedność duchową. Jestem także oblatem klasztoru w Tyńcu"29.

${ }^{28} \mathrm{~W}$ archiwum prywatnym autora. Sygn. JB 2005/3/20.

${ }^{29}$ Czym jest oblatura? Kim jest oblat benedyktyński? O. Gabriel Brasò OSB wytłumaczył to w jasny sposób: „Oblat to chrześcijanin, pragnący z przekonaniem i głęboko żyć Ewangelią; który odkrył w regule św. Benedykta oświecającą drogę, która ułatwia mu podążanie za Chrystusem i pobudza go do służenia Bogu i braciom z czystszą miłością, drogę, która czyni go bardziej wspaniało- 
8 kwietnia 2005 r. oczy całego świata były zwrócone w kierunku placu św. Piotra, na którym trwał pogrzeb papieża Jana Pawła II. Liturgię, pod przewodnictwem kard. Josepha Ratzingera, koncelebrowało 160 kardynałów i patriarchów wschodnich Kościołów katolickich. Hołd zmarłemu, obok oficjalnych delegacji szefów państw, koronowanych głów i ministrów, oddało również 16 przywódców religijnych. W czasie tych uroczystości Komunię św. z rąk kard. Ratzingera przyjął brat Roger Schutz, znany całemu światu założyciel ekumenicznej wspólnoty w Taizé, który starał się realizować chrześcijański ideał pojednania i współistnienia ludzi różnych wyznań. Wówczas w różnych środowiskach i mediach pojawiły się pytania, czy przyjęcie Komunii św. przez brata Rogera, który był członkiem Kościoła ewangelicko-reformowanego, było wydarzeniem jednorazowym, swego rodzaju precedensem, czy może brat Roger skrywał swoją konwersję i ujawnił ją światu w tej szczególnej historycznej chwili? Szczegółowa analiza biografii założyciela Wspólnoty ekumenicznej wskazuje, że posiadał on specjalne papieskie zezwolenie na przystępowanie do Komunii św. Przebywał on wielokrotnie w Watykanie i w papieskiej kaplicy, podczas mszy świętej przystępował do Stołu Pańskiego. Również przebywał z wizytą u kard. Karola Wojtyły, gdzie podczas Mszy św. w kaplicy kurialnej przyjmował Komunię św. Pod koniec lat siedemdziesiątych XX stulecia, będąc na pielgrzymce mężczyzn i młodzieńców w Piekarach Śląskich, przystąpił do Komunii św.

Kolejnym przykładem pragnienia wspólnoty stołu eucharystycznego było spotkanie księdza katolickiego ze starszą kobietą w Cieszynie w grudniu 2016 r. podczas odwiedzin chorych i starszych parafian z Komunią św. Wchodząc do jednego z bloków mieszkalnych, kapłan został pozdrowiony słowami: „Dzień dobry". Przedstawiła się, że jest ewangeliczką. Kapłan odwzajemnił pozdrowienie, a następnie złożył jej życzenia świąteczne. Spotkana osoba zapytała: „A czy ja mogę Panu złożyć życzenia?”. „Tak, oczywiście” - odpowiedział proboszcz. Kobieta zakończyła życzenia pytaniem: „Czy ja mogę pocałować Pana Jezusa, którego ksiądz niesie do ludzi, bo ja w ten sposób chciałabym uczcić Jezusa, którego jeszcze nie mogę przyjmować w Waszym kościele?”. Ksiądz odpowiedział: „Proszę bardzo”. W taki sposób kobieta okazała cześć i szacunek dla sakramentu Eucharystii.

Można wymienić wiele przykładów odnośnie do Eucharystii w praktyce ekumenicznej Kościoła katolickiego. Kościół katolicki dopuszcza w pewnych - nadzwyczajnych - okolicznościach do Komunii eucharystycznej, ale tylko tych, którzy pozostają z nim w jedności wiary, kultu i życia eklezjalnego. Te przypadki

myślnym w przeżywaniu swojego stanu życia (...)”. Oznacza to, że oblatem może być mężczyzna i kobieta, świecki i kapłan, osoba żyjąca w małżeństwie i samotna. Oblatura benedyktyńska jest drogą, która służy za wsparcie i która pomaga człowiekowi żyć jego własnym powołaniem. Por. Archiwum prywatne autora, sygn. JB 2009/3/21. 
odnoszą się do sytuacji indywidualnej konieczności fizycznej. Taką nadzwyczajną okolicznością jest m.in.: niebezpieczeństwo śmierci, kiedy osoba z innego Kościoła (np. protestanckiego, prawosławnego czy anglikańskiego) zwraca się z prośbą do duchownego rzymskokatolickiego o udzielenie Komunii św., gdyż nie istnieje w danej chwili możliwość skorzystania z niej w jej Kościele. Warunkiem koniecznym jest wyznanie wiary przez tę osobę. Ekumeniczne dokumenty Kościoła zwracają uwagę na to, że te wskazania winny być ustalone z miejscowym biskupem ordynariuszem, bądź uznane przez Konferencję Episkopatu ${ }^{30}$.

W dokumencie kard. W. Kaspera, zatytułowanym Zaangażowanie ekumeniczne Kościoła katolickiego, autor wspomina wypowiedź biskupa Wiednia, kard. Christopha Schönborna, w którym zostały przedstawione konkretne kryteria odnoszące się do owych sytuacji. Jako przykład takiego przypadku kardynał podaje osobę ochrzczoną (niekatolika), która pragnie z poważnych powodów osobistych czynnie uczestniczyć w katolickiej Eucharystii i która w zakończeniu modlitwy eucharystycznej w szczerej wierze, wraz z całą społecznością liturgiczną, może powiedzieć, , «Amen» na to, co modlitwa eucharystyczna głosi, i na to, co dzieje się podczas nabożeństwa wedle wyznania katolickiego. Dlatego ten, który mówi «tak» tej komunii i potwierdza to przez swoje «Amen», jest w komunii eklezjalnej przez swoje osobiste przekonanie; przeciwnie, kto uważa tę komunię za niezgodną z własnym wyznaniem wiary, ten nie może, jeśli jest szczery, chcieć w niej uczestniczyć" 31 .

W gestii Konferencji Episkopatu lub biskupa ordynariusza jest możliwość podania szczegółowych zasad przyjęcia Komunii św. przez niekatolików. Jeżeli powyższe władze wyrażą na to zgodę, a zebrani na liturgii wyznają wiarę w ten sakrament i spełnią wymagania moralne, to wówczas, w czasie np. pogrzebów, uroczystości rodzinnych i zawierania małżeństw osób o różnej przynależności wyznaniowej, można tym osobom udzielić Komunii św. (por. KPK 844, § 4; Dyr. Ek 131). Należy zaznaczyć, że wierni Kościoła katolickiego nie mają możliwości przyjmowania sakramentu pokuty, namaszczenia chorych i Eucharystii w Kościołach niekatolickich. Brak możliwości korzystania z sakramentów nie odbiera jednak katolikom możliwości uczestniczenia w nabożeństwach w tych Kościołach (Dyr. Ek 118). Może zaistnieć taka sytuacja, że katolik nie może uczestniczyć we Mszy św. niedzielnej w swoim Kościele, wówczas winien udać się do innego Kościoła chrześcijańskiego na liturgię, która będzie dla niego pogłębieniem życia duchowego, a zarazem znakiem przyszłej jedności Kościoła.

Bardzo ważnego znaczenia nabierają słowa brata Rogera Schutza wypowiedziane w 1980 r. podczas Europejskiego Spotkania Młodych w Rzymie w obec-

30 Por. Dyr. Ek 129-130; DE 8; KPK 844 § 2-4.

31 W. Kasper, Zaangażowanie ekumeniczne Kościoła katolickiego, BE (2002) nr 3-4, 19-20. 
ności papieża Jana Pawła II oraz zgromadzonych w Bazylice Świętego Piotra młodych: „Znalazłem moją chrześcijańską tożsamość, jednając w sobie samym wiarę mego pochodzenia z tajemnicą wiary katolickiej, nie zrywając z nikim komunii" 32 . Słowa te mogą stanowić jeden z poszukiwanych wzorców w dążeniu do jedności, do pojednania chrześcijan.

Postawa różnych tradycji wobec problemu interkomunii jest motywowana odmiennymi założeniami teologicznymi. Jednakże doświadczenie uczy, że niekiedy dynamika ekumeniczna wystawia doktryny kościelne na próbę, oraz że chrześcijanie różnych konfesji poprzez pragnienie wspólnej komunii eucharystycznej skutecznie realizują drogę ku pełniejszej wspólnocie.

\section{Zakończenie}

Katolicy, ewangelicy i chrześcijanie różnych konfesji żyją razem jako sąsiedzi, spotykają się w pracy i uczą się żyć wśród ludzi innych religii. Należy nieustannie uświadamiać sobie i rozwijać w sobie to, co jest w naszej wierze wspólne, oraz dążyć do jedności, chociaż ujawniają się jeszcze między nami różnice. Chrzest i Eucharystia to dwa sakramenty uznawane przez wszystkich chrześcijan. Co do chrztu świętego panuje zasadnicza zgoda. Chrzest udzielony w jednym z Kościołów jest uznawany za ważny w innych. Podobnej zgody brak w odniesieniu do Eucharystii. Uznanie chrztu nie prowadzi do uczestnictwa w jednej Eucharystii. Chrześcijanie, chociaż mają pragnienie, wciąż nie mogą zjednoczyć się w pełnej wspólnocie wokół jednego ołtarza, aby spożywać ten sam chleb eucharystyczny i pić z jednego kielicha. Ta sytuacja jest sprzeczna z wolą Jezusa, który modlił się podczas Ostatniej Wieczerzy, ,aby wszyscy byli jedno”. Eucharystia jest sakramentem komunii, czyli wspólnoty nie tylko człowieka z Bogiem, ale także ludzi ze sobą. Dramat podziału widać szczególnie w tym kontekście. Nie może on być czymś obojętnym dla chrześcijan.

Ruch ekumeniczny jest nieodwracalnym procesem zarówno na płaszczyźnie duchowej, jak i w codziennej praktyce. Ekumenizm bowiem to już nie tylko „znak czasu”, ale to obowiązek i odpowiedzialność wobec Boga i Jego zbawczego zamysłu, spoczywająca na tych, którzy przez chrzest stali się Ciałem Chrystusa i nowym Jego ludem. Jednocześnie dążenie do pojednania winno być wewnętrznym głosem sumienia chrześcijańskiego, oświeconego wiarą i kierowanego miłością.

32 Por. J. Brożek, Droga Brata Rogera, TP (2006) nr 38, 2. 


\section{Bibliografia}

BudNIAK J., Ekumenizm jutra na przykładzie Śląska Cieszyńskiego, Katowice 2002.

BudNIAK J., W jakich okolicznościach można udzielić Komunii św. niekatolikom, „Homo Dei” (2008) nr 1, s. 129-135.

Ebeling G., Sui Salmi, Brescia 1971.

Maciuszko J.T., Kościół luterański w Polsce od XVI do XX wieku, w: J. Below,

M. Legendź (red.), Świadectwo wiary $i$ życia Kościół luterański $w$ Polsce wczoraj i dziś, Bielsko-Biała 2004, s. 55-104.

JAN PAWE⿺ II, Adhortacja apostolska o zadaniach rodziny chrześcijańskiej w świecie współczesnym „,Familiaris consortio”, Watykan 1981.

JAN PAWE⿺ II, Encyklika Ecclesia de Eucharistia, Wrocław 2003.

JASKÓŁa P., Zagadnienia ekumeniczne, Opole 2004.

Kaszowski M., Podstawy nauki Kościoła katolickiego w pytaniach i odpowiedziach, w: www. teologia.pl, s. 1 (28.01.2017).

Katechizm Kościoła Katolickiego, Poznań 1994.

Koch K., BIEL R., Symfonia jedności, Lublin 2015.

Kосн K., Dzięki małżeństwom mieszanym możemy realizować praktyczny ekumenizm, http://niedziela.pl/artykut/18380/Kard-Koch-dzieki-malzenstwom-mieszanym (23.02.2017).

Kodeks Prawa Kanonicznego (1983), Poznań 2008.

Konfesja Augsburska IX. O chrzcie, http://old.luteranie.pl/www/biblioteka/dpisma/ka.pdf (04.02.2017).

LuTER M., Duży katechizm, http://luter2017.pl/wp-content/uploads/pdf/DuzyKatechizm.pdf (12.02.2017).

Nossol A., Ekumenizm jako imperatyw chrześcijańskiego sumienia, Opole 2000.

Nossol A., Wspólnota ekumeniczna - troska o budowę zjednoczonej Europy jako wspólnoty wartości i kultury, ,Studia Oecumenica” 6 (2006), s. 65-178.

Od konfliktu do komunii. Luterańsko-katolickie wspólne upamiętnienie reformacji w 2017 roku, tłum. D. Bruncz, Dzięgielów 2013.

Przemówienie Jana Pawła do przedstawicieli Equipe Notre-Dame wygłoszone 20 stycznia 2003 roku: Eucharystia źródtem siły dla matżonków i rodziców, „L'Osservatore Romano” (2003) nr 3, s. 25.

Sakrament chrztu świętego, w: M. LuTER, Mały katechizm, http:/www.diec.warszawska.luteranie.pl/pobierz/Mały_Katechizm.pdf (12.02.2017).

Sakrament chrztu znakiem jedności. Deklaracja Kościołów w Polsce na progu trzeciego tysiąclecia (Warszawa, 23 stycznia 2000r.), w: J. BudNiAK, Z. Glaeser, T. KaŁużny, Z.J. KiJas (red.), Encyklopedia ekumenizmu w Polsce (1964-2014), Kraków 2016, s. 514-515. 
SKowroneK A., Sakramenty wiary. Spotkania z Chrystusem w Kościele w profilu ekumenicznym, t. V, Włocławek 1998.

Sztafrowski E., Posoborowe prawo kościelne, t. III, z. 2, Warszawa 1971.

Wiara, modlitwa i życie w Kościele Katowickim. Uchwaty I Synodu Diecezji Katowickiej 1972-1975, Katowice - Rzym 1976. 